DOI: https://doi.org/10.32689/2523-4536/59-5

УДК 338.330 .141

Драган I. B.

кандидат економічних наук, доцент, старший науковий співробітник відділу методології сталого розвитку, ДУ «Інститут економіки природокористування та сталого розвитку

Національної академії наук України»

ORCID: https://orcid.org/0000-0002-6906-5000

Туболець I. I.

кандидат економічних наук, доцент, доцент кафедри соціального забезпечення та податкової політики,

Університет митної справи та фінансів ORCID: https://orcid.org/0000-0002-4930-2427

Dragan Irina

Ph.D. (in Economics), Associate Professor, Senior Research Fellow Department of Sustainable Development Methodology, Public Institution «Institute of Environmental Economics and Sustainable Development of the National Academy of Sciences of Ukraine»

Tubolets Iryna

Candidate of Economic Sciences, Associate Professor, Associate Professor of the Department of Social Security and Tax Policy, University of Customs and Finance

\title{
ФОРМУВАННЯ КОМПЛЕКСНОЇ СИСТЕМИ УПРАВЛІННЯ ЕФЕКТИВНІСТЮ ГОСПОДАРСЬКОЇ ДІЯЛЬНОСТІ ПРОМИСЛОВОГО ПІДПРИЕМСТВА
}

\section{FORMATION OF A COMPREHENSIVE MANAGEMENT SYSTEM FOR THE EFFICIENCY OF ECONOMIC ACTIVITY OF AN INDUSTRIAL ENTERPRISE}

\begin{abstract}
У статті проаналізовано питання сталого розвитку промислових підприємств. Описано проблемні питання забезпечення ефективності господарської діяльності в даний час. Розглянуто різні підходи до оиінки сталого розвитку промислового підприємства. Особливу увагу в статті приділено класифікації резервів економічної стійкості промислового підприємства. Доведено, щзо одним з найбільш важливих факторів оцінки конкурентоспроможності на ринку є показник стійкості організації.
\end{abstract}

Ключові слова: сталий розвиток, стійкість промислового підприємства, оцінка економічної стійкості, резерви економічної стійкості.

The article analyzes the issues of sustainable development of industrial enterprises. The problematic issues of ensuring the sustainability of economic activity at present are described. Different approaches to the assessment of sustainable development of an industrial enterprise are considered. The article pays special attention to the classification of reserves of economic stability of an industrial enterprise. It is proved that one of the most important factors in assessing competitiveness in the market is the indicator of stability of the organization. Modern industrial enterprises operate in conditions of high uncertainty and risk, as well as the dynamics of the external environment. For them, sustainability becomes the main condition for survival and development, increasing competitiveness in foreign and domestic markets, establishing long-term partnerships with stakeholders. Thus, the main parameters for diagnosing the degree of stability of industrial enterprises can be considered the degree of use of such reserves as reserves in reducing the duration of the production cycle, reserves to improve the use of tools and labor, reserves to improve product quality and efficiency reserves. use of labor.

Keywords: sustainable development, stability of industrial enterprise, assessment of economic stability, reserves of economic stability.

Вступ. Підходи, які використовуються вітчизняними промисловими підприємствами для управління своєю ефективністю, значно змінилися в останні десятиліття, відповідно до нинішніх ринкових умов. Вплив наслідків кризи на вітчизняну економіку призвів до підвищення нестійкості і наростання невизначеності зовнішнього середовища, зниження 
рівня конкуренції на ринку і істотного скорочення бюджетного фінансування економіки, в тому числі державного замовлення. 3 урахуванням цих обставин керівникам доводиться розробляти інструменти контролю діяльності, які могли б датти змогу їм швидко і адекватно оцінювати стан підприємства і розробляти комплекси заходів для вирішення виникаючих проблем. Таким чином, використання різних механізмів контролю та оцінки поточного стану $є$ інструментом управління в умовах агресивного зовнішнього середовища.

Важливість оцінки сталого розвитку промислового підприємства $є$ не тільки групою параметрів управління, а й засобом для здійснення стратегічного планування на основі самоідентифікації підприємства, глибокого внутрішнього аналізу і виявлення причин, що перешкоджають успішному розвитку. При відсутності тривожних сигналів існує можливість зміцнення становища на ринку і підвищення ефективності. Сталий розвиток підприємства підвищує свою інвестиційну привабливість і має можливість розширення своєї діяльності на нових напрямках. Послідовно проводячи політику покрокової стабілізації підприємство функціонує на більшій кількості сегментів, що дає змогу диверсифікувати види діяльності та підвищити ринкову стійкість.

Таким чином, проблема розробки оцінки сталого розвитку промислового підприємства $\epsilon$ актуальною, а їі розгляд і рішення дозволить підприємствам більш ефективно управляти своєю діяльністю як в умовах позитивної, так і негативної динаміки.

Постановка проблеми. Метою статті $\epsilon$ оцінка ефективного розвитку господарської діяльності промислового підприємства.

Результати. Реалії сучасної економіки неминуче призводять до того, що підприємствам досить складно утримувати свою позицію на ринку. У зв'язку з постійно зростаючим рівнем конкуренції компаніям необхідно розробляти різні заходи для закріплення за собою ніші того чи іншого сегмента ринку. Зазначене залежить перш за все від рівня конкурентоспроможності підприємства, що виявляється через якість продукції у порівнянні з іiі ціною. Одним з найбільш важливих факторів оцінки конкурентоспроможності на ринку $є$ показник стійкості організації. Виділяють кілька підходів до визначення поняття «стійкість» [5, с. 113-117]:

- економічна стійкість ототожнюється 3 фінансовою стійкістю;

- під економічною стійкістю підприємства розуміється надійність і стабільність його фінансово-господарської діяльності;
- під економічною стійкістю підприємства розуміється можливість даного підприємства зберігати і підтримувати поточний стан функціонування, вміння адаптуватися до різних змін зовнішнього і внутрішнього середовища;

- під економічною стійкістю підприємства розуміється процес підтримки певного допустимого рівня кількісних і якісних показників і характеристик підприємства, в рамках якого забезпечується достатній рівень рентабельності його функціонування і стабільний розвиток;

- 3 точки зору теорії максимізації прибутку під економічною стійкістю підприємства мається на увазі певний стан підприємства, що дає йому можливість зберігати прибуток на заданому рівні;

- під економічною стійкістю підприємства розуміється сукупність властивостей виробничої, господарської, фінансово-кредитної, інноваційної діяльності цього підприємства, їх взаємодія, новизна і якість виробленої продукції, стабільний рівень ресурсного забезпечення підприємства, характер кадрового, інноваційного, фінансового менеджменту;

- 3 точки зору відтворювального підходу під економічною стійкістю підприємства розуміється процес забезпечення своєчасної науково-відтворювальної діяльності в умовах нестабільності і невизначеності ринків;

- 3 точки зору економічної кібернетики під економічною стійкістю підприємства розуміється можливість підприємства знайти найбільш оптимальне співвідношення між іiї елементами, здатними протистояти негативним впливам навколишнього середовища;

- під економічною стійкістю підприємства розуміється стабільне отримання підприємством доходів від продажів.

Як наукова категорія економічна стійкість характеризує особливий стан функціонування підприємства в умовах складного ринкового середовища. Під економічною стійкістю підприємства розуміється процес підтримки певного рівня кількісних і якісних показників i характеристик підприємства, в рамках якого забезпечується достатній рівень рентабельності його функціонування і стабільний розвиток. Виділяють ряд критеріїв для характеристики економічної стійкості виробничої системи: стійкість забезпечення ресурсами, стійкість виробничої і господарської діяльності, стійкість фінансової і збутової діяльності, стійкість виробничо-технічної сфери та інвестиційної діяльності [4, с. 18-22].

Також існують певні складові економічної стійкості виробничих систем: фінансова стійкість, податкова стійкість, стійкість ціни про- 
дукції, ринкова стійкість, стійкість ділових відносин, стійкість виробничої діяльності, управлінська стійкість, інвестиційна стійкість, кадрова стійкість [6, с. 55-59]. В даний час для успішного існування та подальшого розвитку підприємствам необхідно проводити оцінку їх економічної стійкості. Оцінка економічної стійкості підприємства дає можливість виявлення його сильних і слабких сторін виходячи 3 отриманих показників ефективності.

Також підприємствам необхідно підвищувати рівень економічної стійкості за рахунок своєчасного виявлення та використання резервів їі підвищення. Існує безліч підходів до оцінки економічної стійкості підприємства:

- традиційний підхід грунтується на оцінці фінансової складової діяльності організації. В рамках цього підходу оцінка економічної стійкості підприємства здійснюється за допомогою наступних показників: коефіцієнт платоспроможності підприємства, коефіцієнт покриття, коефіцієнт автономії, частка власного капіталу в оборотних коштах тощо;

- ресурсний підхід грунтується на оцінюванні ресурсів. В рамках цього підходу економічна стійкість підприємства оцінюється через такі показники: фондовіддача, фондомісткість, фондоозброєність, рентабельність, трудомісткість, вироблення, матеріаломісткість, матеріаловіддача тощо;

- ресурсно-управлінський підхід грунтується на оцінці ресурсів і якості управління. В рамках цього підходу оцінка економічної стійкості підприємства здійснюється за допомогою наступних показників: коефіцієнт автономії, коефіцієнт поточної ліквідності, коефіцієнт поточної платоспроможності, коефіцієнти фінансової стійкості підприємства 3 урахуванням якості управління, забезпеченості запасами та ефективності використання ресурсів тощо;

- стохастичний аналіз, в рамках якого отримані значення фінансових показників оцінюють 3 точки зору того, в якій зоні вони знаходяться (допустима, задовільна, критична);

- підхід з використанням теорії нечітких множин. Для кожного фінансового показника визначаються так звані кордони нечітких підмножин. Здійснюється оцінка існуючого рівня показника, проводиться класифікація даного рівня показника за підмножинами і на основі цього виявляються значення, які дають змогу здійснити оцінку фінансової стійкості.

Деякі автори виділяють підхід до оцінки економічної стійкості підприємства, заснований на виділенні показників в різних групах [3]:
- фінансова група: коефіцієнт забезпеченості підприємства власними коштами, коефіцієнт співвідношення коштів власних $\mathrm{i}$ позикових, коефіцієнт забезпеченості запасів і витрат за рахунок власних джерел, коефіцієнт інвестування, економічна рентабельність, фінансова рентабельність, коефіцієнт фінансової стійкості (стабільності), коефіцієнт автономії, коефіцієнт рентабельності продажів, коефіцієнт поточної ліквідності, коефіцієнт оборотності;

- виробнича група: фондовіддача основних фондів, фондоозброєність, коефіцієнт придатності основних фондів, коефіцієнт завантаження виробничої потужності;

- кадрова група: продуктивність праці, середньомісячна заробітна плата працівників, рівень освіти промислово-виробничого персоналу, коефіцієнт стабільності кадрів;

- маркетингова група: темп зростання ринкової частки, темп зростання обсягу продажів.

При виборі основних показників оцінки економічної стійкості підприємства можуть використовувати як класичний, так і узагальнюючий підхід. Узагальнюючий підхід грунтується на використанні показників, які показують кінцеві результати діяльності підприємства. До них відносяться показники, що характеризують ефективність використання основних фондів (питома вага, коефіцієнт зносу, коефіцієнт оновлення, коефіцієнт вибуття, фондовіддача, фондомісткість), матеріальних ресурсів (питома матеріаломісткість, матеріаломісткість, матеріаловіддача, коефіцієнт матеріальних витрат), трудових ресурсів (продуктивність праці, трудомісткість, прибуток на одного працівника) $[2$, c. 15$]$.

Класичний підхід грунтується на застосуванні показників, які характеризують певну сторону діяльності підприємства і застосовуються також для виявлення резервів підвищення економічної стійкості підприємства. До таких показників відносяться фінансові показники (рентабельність, ліквідність, оборотність, показники фінансової стійкості), показники, що характеризують маркетингову діяльність, кадрове управління. Ще одним методом оцінки економічної стійкості підприємства можна вважати метод кількісної інтегральної оцінки. В результаті здійснення оцінки даним методом після проведення розрахунків інтегральних показників виділяються сім рівнів економічної стійкості підприємства:

1. Ідеальне (характеризується високою конкурентоспроможністю підприємства, цілісністю, не схильне до впливів зовнішніх фак- 
торів, так як зазвичай є стратегічним монопольним підприємством держави).

2. Відмінне (характеризується високою конкурентоспроможністю, цілісністю, здатністю протистояти змінам зовнішнього середовища).

3.Гарне (характеризується стійкою конкурентоспроможністю, цілісністю, здатністю протистояти змінам зовнішніх чинників).

4.Задовільний (характеризується низькою конкурентоспроможністю, цілісністю, слабкою здатністю протистояти змінам зовнішніх чинників).

5.Незадовільний (характеризується неконкурентоспроможністю, цілісністю, слабкою здатністю протистояти змінам зовнішніх чинників).

6.Кризовий (характеризується неконкурентоспроможністю, частковим виконанням своїх функцій, цілісністю, нездатністю протистояння змінам зовнішніх факторів).

7. Ліквідаційна (стан підприємства характеризується неконкурентоспроможністю, невиконанням своїх функцій, порушенням цілісності, нездатністю протистояння змінам зовнішніх чинників).

Таким чином, існує безліч методик оцінки стійкості підприємства. Але слід зазначити, що визначити, стійкість підприємства на ринку, виходячи з оцінки тільки одного фактора або використовуючи один вид або групу показників, неможливо. Для визначення стійкості промислового підприємства необхідно проводити комплексну оцінку, засновану на розрахунку i вивченні фінансових, маркетингових, виробничих, трудових показників діяльності підприємства.

Для постійного повноцінного забезпечення і підтримки необхідного рівня економічної стійкості промислового підприємства потрібно своєчасне виявлення і використання резервів іії збільшення.

Резерви сталого розвитку пропонується класифікувати за наступними критеріями:

- в залежності від сфери діяльності підприємства: внутрішні резерви (кадрові, фінансові, матеріально-технічні); зовнішні резерви (перерозподіл коштів, що виділяються між підприємствами однієї галузі);

- в залежності від терміну мобілізації: поточні резерви (мобілізуються протягом одного року); перспективні резерви (мобілізуються в довгостроковий період);

- в залежності від можливості виявлення: явні резерви; приховані резерви;

- в залежності від внутрішньої сутності резервів: кількісні резерви (збільшення відпрацьованого часу); якісні резерви (зниження трудомісткості продукції, що виготовляється);
- в залежності від впливу на економічні показники: резерви прямого впливу (запуск нового обладнання); резерви непрямого впливу (поліпшення культурно-побутових умов працівників);

- в залежності від способів обчислення: комплектні резерви; резерви підвищення ефективності використання конкретних видів ресурсів виробничого характеру.

Під резервами підвищення економічної стійкості виробничої системи розуміються невикористані можливості збільшення ступеня задіяння внутрішніх чинників, що формують економічну стійкість підприємства і дають можливість забезпечити його діяльність на конкретному ринку в умовах існуючих змін факторів зовнішнього середовища для досягнення цілей збільшення обсягів продажів і зростання прибутку [1].

Можна виділити наступні види резервів збільшення економічної стійкості виробничих систем:

- резерви підвищення ефективності використання знарядь і предметів праці на підприємстві;

- резерви збільшення якості продукції (невикористані можливості поліпшення якості продукції, що випускається, технікоекономічних характеристик);

- резерви скорочення тривалості виробничого циклу;

- резерви підвищення стійкості виробничого рівня підприємства (розробка та впровадження нових систем планування, вдосконалення структури виробництва);

- технологічні резерви (можливості збереження якості продукції при економії іiі виробництва, прискорення впровадження нових технологій і техніки);

- резерви підвищення фінансової стійкості підприємства;

- резерви підвищення стійкості персоналу підприємства (підвищення стабільності кадрів, оновлення знань працівників);

- резерви, що впливають на кінцеві фінансові результати діяльності підприємства.

Висновки. Сучасні промислові підприємства функціонують в умовах високого ступеня невизначеності і ризику, а також динамічності зовнішнього середовища. Для них формування комплексної системи управління ефективністю господарської діяльності стає основною умовою виживання і розвитку, підвищення конкурентоспроможності на зовнішньому і внутрішньому ринках, встановлення довгострокових партнерських відносин зі стейкхолдерами. Таким чином, в якості основних параметрів діагностики ступеня 
стійкості промислових підприємств можна розглядати ступінь використання таких резервів, як резерви у сфері скорочення тривалості виробничого циклу, резерви поліпшення використання знарядь праці i предметів праці, резерви поліпшення якості продукції, що випускається, а також резерви підвищення ефективності використання робочої сили.

\section{Список використаних джерел:}

1.Демешок О.О., Микитенко В.В. Економічна безпека промисловості: цільовий функціонал та технології управління : Монографія. За наук. редакцією д.е.н., проф. Микитенко В.В. Київ : ДУ «Інститут економіки природокористування та сталого розвитку НАН України», МНТУ ім. академіка Юрія Бугая МОНмолодьспорту України, 2012. 650 с.

2.Ігнатьєва I.А. Методологічні аспекти управління стратегічним потенціалом промислового підприємства. Проблеми науки : міжгалузевий науково-практичний журнал. Державне підприємство «Центр науково-технічної інформації та сприяння інноваційному розвитку України», 2005. № 1. С. 8 - 15 .

3.Ладонько Л.С. Концептуальні основи інноваційного розвитку промисловості у контексті глобалізаційних процесів науково-технічного прогресу. Формування ефективних механізмів управління в умовах пріоритетності знаннєвої компоненти економічного розвитку: Монографія [С.М. Вдовенко, I.C. Каленюк, Л.С. Ладонько та ін.; за ред. к.е.н., доц. Л. Ладонько]. Ніжин : ТПК «Орхідея», 2013. 347 с.

4.Мельник Л.Г. Рождение сестейновой экономики: Опыт ЕС и практика Украины в свете III и IV промышленных революций : монографія. Сумы : Университетская книга, 2018. 430 с.

5.Соціально-економічний потенціал сталого розвитку України та iï регіонів: вектори реального поступу. Національна доповідь / за ред. акад. НАН України Е.М. Лібанової, акад. НААН України М.А. Хвесика. Київ : ДУ ІЕПСР НАН України, 2017. 864 с.

6.Шкарлет С.М., Микитенко В.В. Чинники генерування результативності технологій управління забезпеченням економічної безпеки у промисловості. Тріада національного відродження: наука освіта - виробництво : Збірник наукових праць; за наук. ред. д.е.н., проф. В.В. Микитенко. Вип. 2. Вид-во ПП Вишемирський В.С., 2012. 144 с.

\section{References:}

1.Demeshok O.O., Mykytenko V.V. (2012) Ekonomichna bezpeka promyslovosti: tsil'ovyj funktsional ta tekhnolohii upravlinnia [Economic security of industry: target functionality and management technologies]. DU «Instytut ekonomiky pryrodokorystuvannia ta staloho rozvytku NAN Ukrainy», MNTU im. akademika Yuriia Buhaia MONmolodsportu Ukrainy, Kyiv, Ukraine.

2.Ihnatieva I.A. (2005) Methodological aspects of managing the strategic potential of an industrial enterprise. Problemy nauky: mizhhaluzevyj naukovo-praktychnyj zhurnal, vol. 1, pp. 8-15.

3.Ladonko L.S. (2013) Kontseptualni osnovy innovatsijnoho rozvytku promyslovosti u konteksti hlobalizatsijnykh protsesiv naukovo-tekhnichnoho prohresu. Formuvannia efektyvnykh mekhanizmiv upravlinnia $v$ umovakh priorytetnosti znannievoi komponenty ekonomichnoho rozvytku [Conceptual foundations of innovative development of industry in the context of globalization processes of scientific and technological progress. Formation of effective management mechanisms in terms of priority of the knowledge component of economic development]. TPK «Orkhideia», Nizhyn, Ukraine.

4.Melnik L.G. (2018) Rozhdenie sestejnovoj jekonomiki: Opyt ES i praktika Ukrainy v svete III $i$ $I V$ promyshlennyh revoljucij [The birth of the sister economy: EU experience and practice of Ukraine in the light of III and IV industrial revolutions]. Universitetskaja kniga, Sumy, Ukraine.

5.(2017) Sotsialno-ekonomichnyj potentsial staloho rozvytku Ukrainy ta ii rehioniv: vektory realnoho postupu. Natsionalna dopovid [Socio-economic potential of sustainable development of Ukraine and its regions: vectors of real progress National report]. DU IEPSR NAN Ukrainy, Kyiv, Ukraine.

6.Shkarlet S.M., Mykytenko V.V. (2012) Factors of generating the effectiveness of management technologies for economic security in industry. Triada natsionalnoho vidrodzhennia: nauka-osvita-vyrobnytstvo, vyp. 2 , pp. 144. 